\title{
Studying local earthquakes in the area Baltic-Bothnia Megashear using the data of the POLENET/LAPNET temporary array
}

\author{
Olga Usoltseva ${ }^{1}$ and Elena Kozlovskaya ${ }^{2,3}$ \\ ${ }^{1}$ Institute of Geospheres Dynamics of the Russian Academy of Sciences, Leninsky Prospect, 38, building 1, \\ 119334, Moscow, Russia \\ ${ }^{2}$ Oulu Mining School, University of Oulu, P.O. Box 3000, 90014 Oulu, Finland \\ ${ }^{3}$ Sodankylä Geophysical Observatory, University of Oulu, P.O. Box 3000, 90014 Oulu, Finland \\ Correspondence to: Olga Usoltseva (kriukova@mail.ru)
}

Received: 19 November 2015 - Published in Solid Earth Discuss.: 8 December 2015

Revised: 10 June 2016 - Accepted: 24 June 2016 - Published: 18 July 2016

\begin{abstract}
Earthquakes in areas within continental plates are still not completely understood, and progress on understanding intraplate seismicity is slow due to a short history of instrumental seismology and sparse regional seismic networks in seismically non-active areas. However, knowledge about position and depth of seismogenic structures in such areas is necessary in order to estimate seismic hazard for such critical facilities such as nuclear power plants and nuclear waste deposits. In the present paper we address the problem of seismicity in the intraplate area of northern Fennoscandia using the information on local events recorded by the POLENET/LAPNET (Polar Earth Observing Network) temporary seismic array during the International Polar Year 2007-2009. We relocate the seismic events using the program HYPOELLIPS (a computer program for determining local earthquake hypocentral parameters) and grid search method. We use the first arrivals of $P$ waves of local events in order to calculate a 3-D tomographic $P$ wave velocity model of the uppermost crust (down to $20 \mathrm{~km}$ ) for a selected region inside the study area and show that the velocity heterogeneities in the upper crust correlate well with known tectonic units. We compare the position of the velocity heterogeneities with the seismogenic structures delineated by epicentres of relocated events and demonstrate that these structures generally do not correlate with the crustal units formed as a result of crustal evolution in the Archaean and Palaeoproterozoic. On the contrary, they correlate well with the postglacial faults located in the area of the BalticBothnia Megashear (BBMS). Hypocentres of local events have depths down to $30 \mathrm{~km}$. We also obtain the focal mech-
\end{abstract}

anism of a selected event with good data quality. The focal mechanism is of oblique type with strike-slip prevailing. Our results demonstrate that the Baltic-Bothnia Megashear is an important large-scale, reactivated tectonic structure that has to be taken into account when estimating seismic hazard in northern Fennoscandia.

\section{Introduction}

Northern Fennoscandia has always been considered an area of intraplate seismicity, with moderate-to-low seismic activity. Due to this, the story of instrumental seismology in the area is short and the present-day network of permanent seismic stations in the region is still not dense enough. That is why progress on understanding where and when earthquakes in the region may occur has been slow. Such areas are often considered potentially attractive for such critical facilities as nuclear power plants, nuclear waste deposits and underground mines, for which proper seismic hazard estimates are required. Hence the study of local seismicity in intraplate areas benefits from deployment of dense temporary networks like SVEKALAPKO (Bruneton et al., 2004; Hjelt et al., 2006; Sandoval et al., 2003, 2004). A new opportunity for investigating intraplate seismicity in Fennoscandia was provided by the POLENET/LAPNET (Polar Earth Observing Network) project.

POLENET/LAPNET was a subproject of the multidisciplinary POLENET consortium (http://www.oulu.fi/ sgo-oty/lapnet), related to seismic studies in the Arc- 
tic during the International Polar Year 2007-2009. The POLENET/LAPNET temporary seismic array was deployed in northern Fennoscandia (Finland, Sweden, Norway and Russia). The array consisted of 35 temporary and 21 permanent seismic stations (Fig. 1a). Most of the stations of the array were equipped with broadband three-component sensors. The array registered waveforms of teleseismic, regional and local events from May 2007 to September 2009. The POLENET/LAPNET project became possible due to close cooperation of 12 organisations from 9 countries (see the list of organisations in the Acknowledgements).

The northern part of the Fennoscandian Shield is a region where the main part of the Earth's crust was formed during Precambrian (Fig. 1b). The Palaeoproterozoic (2.5-1.6 Ga) is the most important crust-forming period. The Palaeoproterozoic evolution of the shield can be divided into several major rifting and orogenic stages. The earlier Proterozoic events in the northern Fennoscandian Shield are the rifting of the Archaean crust between 2.5 and $2.1 \mathrm{Ga}$, and consequent drifting and separation of the cratonic components by newly formed oceans (Lahtinen et al., 2008). During the later Palaeoproterozoic, $1.95-1.8 \mathrm{Ga}$, the fragments of previously dispersed Archaean crust were partly reassembled, which resulted in formation of the collisional orogen. The region of our study (Fig. 1, Region 1) comprises the non-reworked part of the Archaean Karelian craton and the part reworked in the Proterozoic (Daly et al., 2006). The area is cut by ancient shear zones (Berthelsen and Marker, 1986; Talbot, 2001) and numerous faults, stretching either from NE to SW or from NW to $\mathrm{SE}$ and $\mathrm{N}$ to $\mathrm{S}$.

According to previous studies (Wu et al., 1999; Arvidsson, 1996; Slunga, 1991; Bungum et al., 2010; Redfield and Osmundssen, 2013, 2015), the local seismicity in northern Fennoscandia can be explained by two factors: a postglacial rebound and spreading in the Mid-Atlantic Ridge (Hess, 1962). According to Lidberg (2010), the maximum vertical velocities in the postglacial uplift area are observed at $19.5^{\circ} \mathrm{E}, 63.6^{\circ} \mathrm{N}$. In our study region the vertical uplift rate varies from 7.7 to $9.9 \mathrm{~mm} \mathrm{yr}^{-1}$. The postglacial faults in Fennoscandia are relatively recent faults formed after the last deglaciation. They are usually several dozen kilometres long with large fault displacements (Kuivamäki et al., 1998; Lagerbäck and Sundh, 2008; Olesen et al., 2004).

The structure of the crust and upper mantle of the Fennoscandian Shield is very complex. It has been studied by different active and passive seismic experiments (Guggisberg, 1986; Guggisberg et al., 1991; Hauser and Stangl, 1990; Sharov, 1993; Luosto et al., 1989; Walther and Fluh, 1993; Kukkonen et al., 2006; Olsson et al., 2008; Eken et al., 2007). Detailed 2-D $P$ velocity models of upper crust along profiles in northern Fennoscandia were calculated in Silvennoinen et al. (2010) and Janik et al. (2009). Regional-scale 3 -D $P$ wave velocity model of the crust for our region was calculated in Glaznev (2003) and Pavlenkova (2006).
Detailed investigation of the Pärvie fault, the world's longest known endglacial fault in the northern Fennoscandia, was performed in Lindblom et al. (2015) on the base of the data from permanent stations of the Swedish National Seismic Network and the temporary network (2007-2010) around the Pärvie fault. Authors used the waveform crosscorrelation technique for detection of microearthquakes near the Pärvie fault and HypoDD (Waldhauser and Ellsworth, 2000) program to improve the location. They found a remarkable correlation between the seismicity and the mapped endglacial fault scarps. They obtained a new 1-D velocity model for this region. The depth of hypocentres of the deepest earthquakes was estimated to be about $35 \mathrm{~km}$. According to Lindblom et al. (2015) the endglacial Pärvie earthquake had a magnitude of $8.0 \pm 0.4$.

The data of the POLENET/LAPNET array were used in several studies aiming to obtain seismic velocity structure of the crust and upper mantle in northern Fennoscandia. A 3-D $S$ wave velocity model of the upper crust was obtained by ambient noise tomography (Poli et al., 2013). Silvennoinen et al. (2014) estimated a new map of the crust-mantle boundary for the POLENET/LAPNET study area using both previous controlled-source seismic profiles and $P$ wave receiver functions calculated for POLENET/LAPNET stations. Teleseismic $P$ wave velocity model of the upper mantle beneath northern Fennoscandia was obtained by Silvennoinen et al. (2015) using teleseismic travel time tomography. Evidence for the upper mantle seismic anisotropy was presented by Plomerová et al. (2011) and Vinnik et al. (2014).

The aim of the present paper is to obtain accurate coordinates of hypocentres of local events recorded by the POLENET/LAPNET array, delineate position and depth penetration of seismogenic structures, and obtain focal mechanism of one selected earthquake with good data quality. In our study, we relocate 34 local earthquakes. Another purpose of our study is to use the local event data (36 earthquakes and 9 explosions) in order to calculate a 3-D tomographic model of the uppermost crust (down to $20 \mathrm{~km}$ ) for a selected region inside the POLENET/LAPNET study area and to obtain new information about structure of the crust there. The present work is continuation of the previous study by Usoltseva et al. (2012).

\section{Data and velocity model}

The seismic stations of the POLENET/LAPNET array were installed on quiet sites. The average spacing between stations is equal to $70 \mathrm{~km}$. The stations recorded continuous data with sampling rate varying from 50 to $100 \mathrm{sps}$. Waveforms were stored in the standard seismological miniSeed format (http: //www.iris.edu/manuals/SEEDManual_V2.4.pdf) in RESIF data centre hosted at Joseph Fourier University (http://portal. resif.fr). 


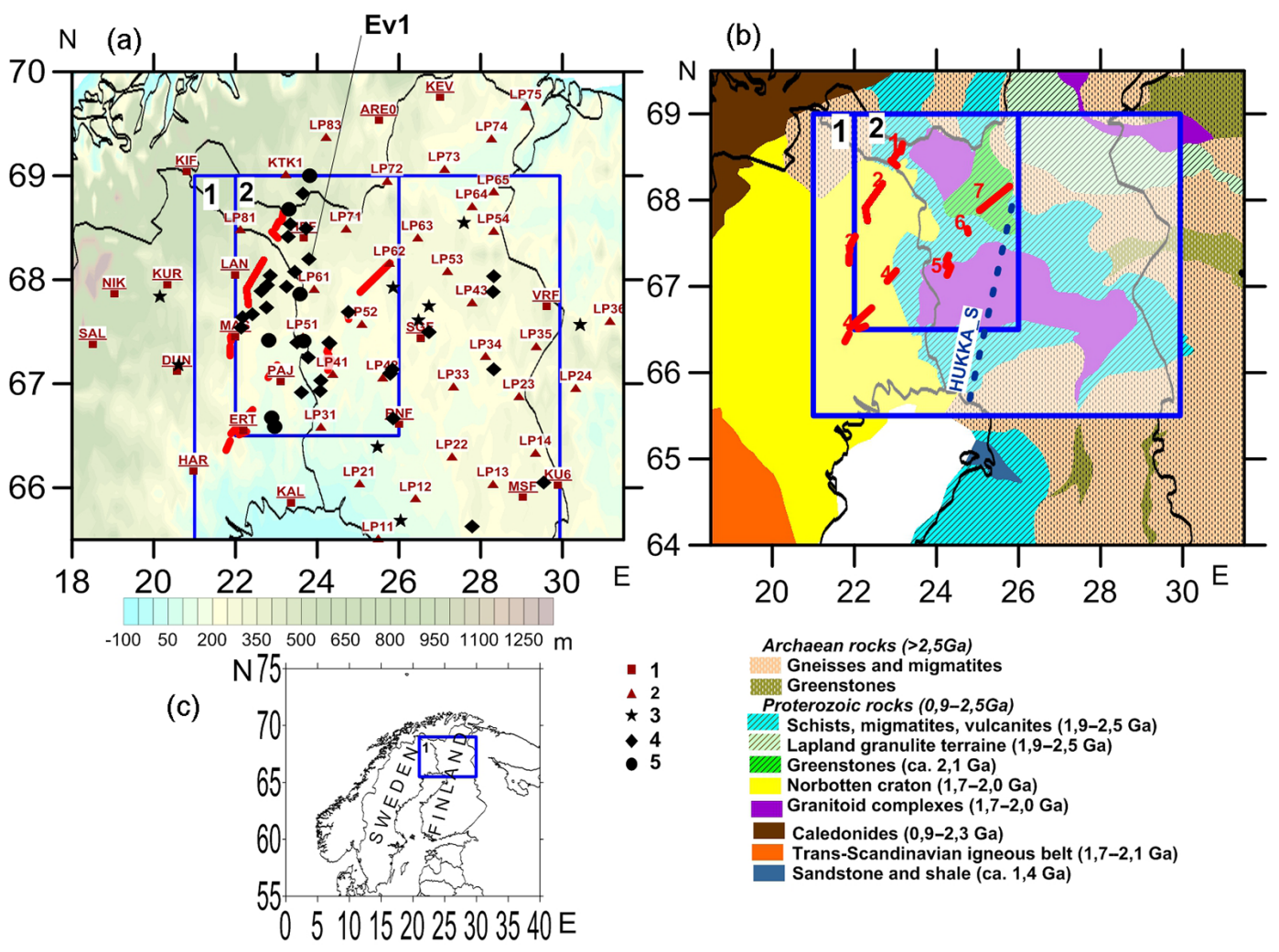

Figure 1. (a) Location of the POLENET/LAPNET stations (1 - permanent, 2 - temporary) and local events ( 3 - explosions, 4 - shallow earthquakes with depths less $20 \mathrm{~km}, 5$ - deep earthquakes), imposed on topographic map ETOPO1 (Amante and Eakins, 2009, http://maps. ngdc.noaa.gov/viewers/wcs-client/); (b) the geological map, based on a 1:2000000 geological map of Fennoscandia (Koistinen et al., 2001); (c) large-scale map for demonstrating where the study area is located in Fennoscandia. Red lines in (b) (with red numerals) are denoted postglacial faults (Sutinen et al., 2014; Mikko et al., 2015): 1 - Palojärvi, Paatsikkajoki and Kultima, 2 - Lainio-Suijavaara, 3 Merasjärvi, 4 - Lansjärv, 5 - Venejärvi, Ruostejärvi and Pasmajärvi, 6 - Isovaara, 7 - Suasselkä. Blue boxes show investigation of Regions 1 and 2. Region 1 is the region for tomographic research and Region 2 is the region for reliable location. Blue dotted line denotes position of the HUKKA S profile. Epicentres are given according to the FENCAT. Ev1 denotes event from Table 4 with determined focal mechanism (the seismic catalogue from all the Nordic countries, www.seismo.helsinki.fi).

Initial information about origin time and hypocentre coordinates of local seismic events was obtained from the seismic catalogue from all the Nordic countries, hereafter FENCAT catalogue (www.seismo.helsinki.fi). According to the FENCAT catalogue, 9174 explosions and 234 earthquakes in northern part of the Fennoscandian Shield occurred during the POLENET/LAPNET data acquisition period. The majority of explosions originated from known quarries, including clusters of epicentres around Kittila gold mine $(\sim 200$ events), Kiruna mine ( 3000 events), Malmberget mine ( $\sim 4000$ events), and the Kovdor and Zapoliarni areas in Russia ( $\sim 400$ events in both areas). In our study we used a set of local earthquakes and explosions with more than six first arrivals of $P$ waves recorded by the POLENET/LAPNET array. Epicentres of these events are shown in Fig. 1a. The seismic waveforms were reviewed with the Seismic Handler (SHM) program package (Stammler, 1993, http://www. seismic-handler.org/portal). Recordings were band-pass filtered with corner frequencies at 1 and $15 \mathrm{~Hz}$ and amplitude- normalised. Examples of seismograms ( $Z$ component) of two local events with different focal depths are shown in Fig. 2.

As can be seen, arrivals of $P$ waves are present at offsets of $25-188 \mathrm{~km}$. A shallow local earthquake with magnitude ML 2.2 and a deep earthquake with magnitude ML 1.6 have distinct $P$ and $S$ wave arrivals, particularly at the short offsets (Fig. 2). For the deep earthquake we observe strong $S$ wave arrivals and weak $P$ wave arrivals at distances less than $100 \mathrm{~km}$ from the epicentre. These amplitudes are also influenced by the radiation pattern of the earthquake. The same tendency for amplitudes of the first arrivals of $P$ and $S$ waves was noticed by Arvidsson et al. (1992) for Skovde earthquake with $\mathrm{ML}$ of 4.5 . The strongest earthquake took place on 19 January 2008 at $19: 52 \mathrm{UTC}\left(67.23^{\circ} \mathrm{N}, 23.80^{\circ} \mathrm{E}\right.$, depth $=10.4 \mathrm{~km}, \mathrm{ML}=2.2$, FENCAT).

As shown by Majdanski et al. (2007), the reliable recognition of different phases of body waves propagating through a 3-D structure and picking-up of their arrivals requires calcu- 
(a)

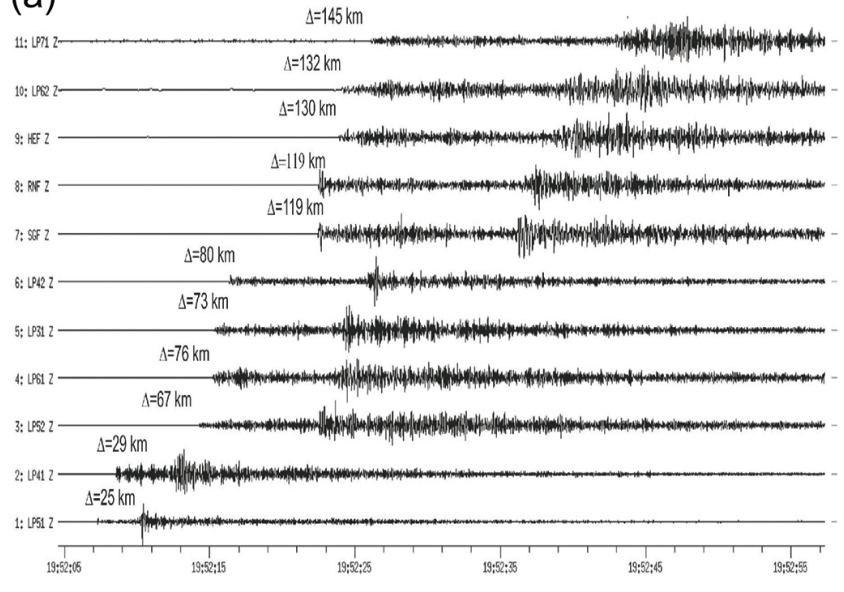

(b)

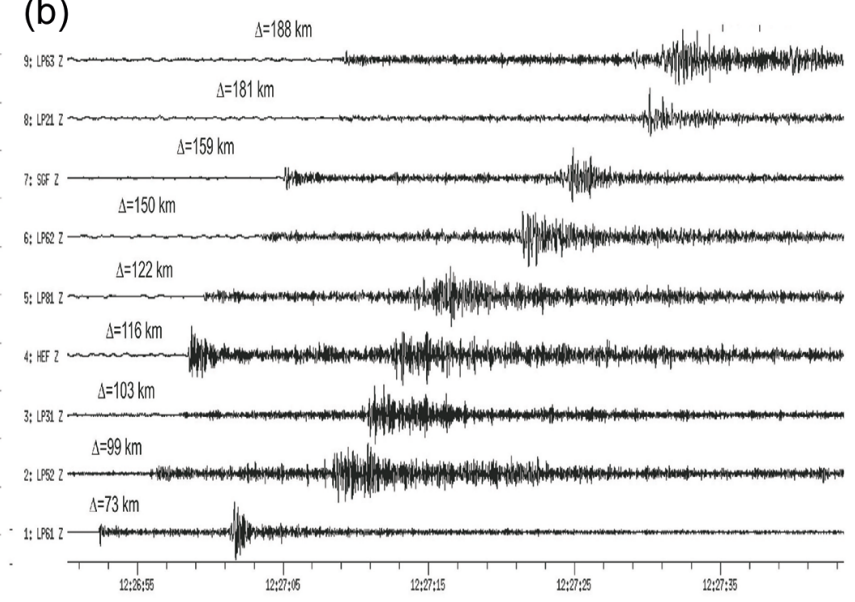

Figure 2. Examples of waveforms of local events in $Z$ component: (a) shallow event on 19 January 2008 at 19:52 $\mathrm{UTC}, 67.23^{\circ} \mathrm{N}, 23.80^{\circ} \mathrm{E}$, depth $=10.4 \mathrm{~km}, \mathrm{ML}=2.2$ (FENCAT); (b) deep event on 03 October 2007 at 12:26 UTC, $67.42^{\circ} \mathrm{N}, 22.81^{\circ} \mathrm{E}$, depth $=27.4 \mathrm{~km}, \mathrm{ML}=1.6$ (FENCAT). Epicentral distances $\Delta$ were calculated using the FENCAT catalogue. Recordings were band-pass filtered with corner frequencies at 1 and $15 \mathrm{~Hz}$ and amplitude normalised.

Table 1. 1-D $P$ wave and $S$ wave velocity models.

\begin{tabular}{lrrr}
\hline $\begin{array}{l}\text { Layer } \\
(\mathrm{km})\end{array}$ & $\begin{array}{r}V_{\mathrm{p}} \\
\left(\mathrm{km} \mathrm{s}^{-1}\right)\end{array}$ & $V_{\mathrm{p}} \times V_{\mathrm{s}}^{-1}$ & $\begin{array}{r}V_{\mathrm{s}} \\
\left(\mathrm{km} \mathrm{s}^{-1}\right)\end{array}$ \\
\hline $0-1.3$ & 6.2 & 1.71 & 3.63 \\
$1.3-18$ & 6.3 & 1.72 & 3.66 \\
$18-37$ & 6.6 & 1.72 & 3.84 \\
$37-40$ & 7.15 & 1.79 & 3.99 \\
$40-44$ & 7.4 & 1.82 & 4.07 \\
$44-50$ & 8.03 & 1.73 & 4.64 \\
Upper 50 & 8.4 & 1.73 & 4.86 \\
\hline
\end{tabular}

lation of theoretical travel times using some a priori-known velocity model.

In our study we used the 1-D velocity model of the HUKKA-S profile (Fig. 1b) published by Janik et al. (2009). The original model consists of six layers in the crust and two layers in the upper mantle. In our work we use a simplified version of this model (Table 1) with five crust layers and two mantle layers. Two upper layers were replaced by one single layer because of their small thicknesses $(0.5$ and $0.8 \mathrm{~km}$ respectively). At the initial stage the trajectories of direct and refracted seismic rays were calculated using Snell's law. The arrival times were picked at seismograms of stations with distances of less than $250 \mathrm{~km}$ from the epicentre.

\section{Relocation of events and determination of focal mechanism for one of them}

For the location of events we used two different methods. One of the methods is HYPOELLIPS (a computer program for determining local earthquake hypocentral parameters;
Lahr, 1989) and the other one is a grid search method (Nelson and Vidale, 1990). The grid search method utilises finite difference computation of the first arrival times (Podvin and Lecomte, 1991). The above-mentioned relocation methods were tested using arrival times of the first arrivals of $P$ and $S$ waves of local explosions from the Hukkavaara hill, for which coordinates of hypocentres are known with high precision (master events). An example of the Hukkavaara explosion with $\mathrm{ML}=1.5$ is presented in Fig. 3, in which event waveforms recorded by the temporary station LP53 and the permanent station HEF (Hetta) are shown. The distance between the explosion and the stations is equal to $59 \mathrm{~km}$ for LP53 and $103 \mathrm{~km}$ for HEF. In seismograms we can see an acoustic signal, which is one of the explosion indicators. In station LP53 the maximal amplitude of the acoustic signal is considerably larger than the maximal amplitude of the seismic signal. At an offset of $103 \mathrm{~km}$ these amplitudes have similar values. Thus in our case the acoustic signal attenuates faster than the seismic one.

The results of testing are presented in Table 2. We found out that the difference of event coordinates obtained by both methods for different explosions is less than $3.7 \mathrm{~km}$, while the difference in origin time is less than $0.1 \mathrm{~s}$.

Table 3 presents results of the relocation of 34 events from Region 2 using both methods with the first arrivals of both $P$ and $S$ waves. After relocation we obtained an rms error of less than $0.4 \mathrm{~s}$ for $85 \%$ of events. The importance of relocation with the help of temporary stations follows from the analysis of hypocentre information from the FENCAT catalogue.

Events from Table 3 were divided into four groups. The first group contains two events, for which the location was not stable. We assume that location is not stable if the differ- 


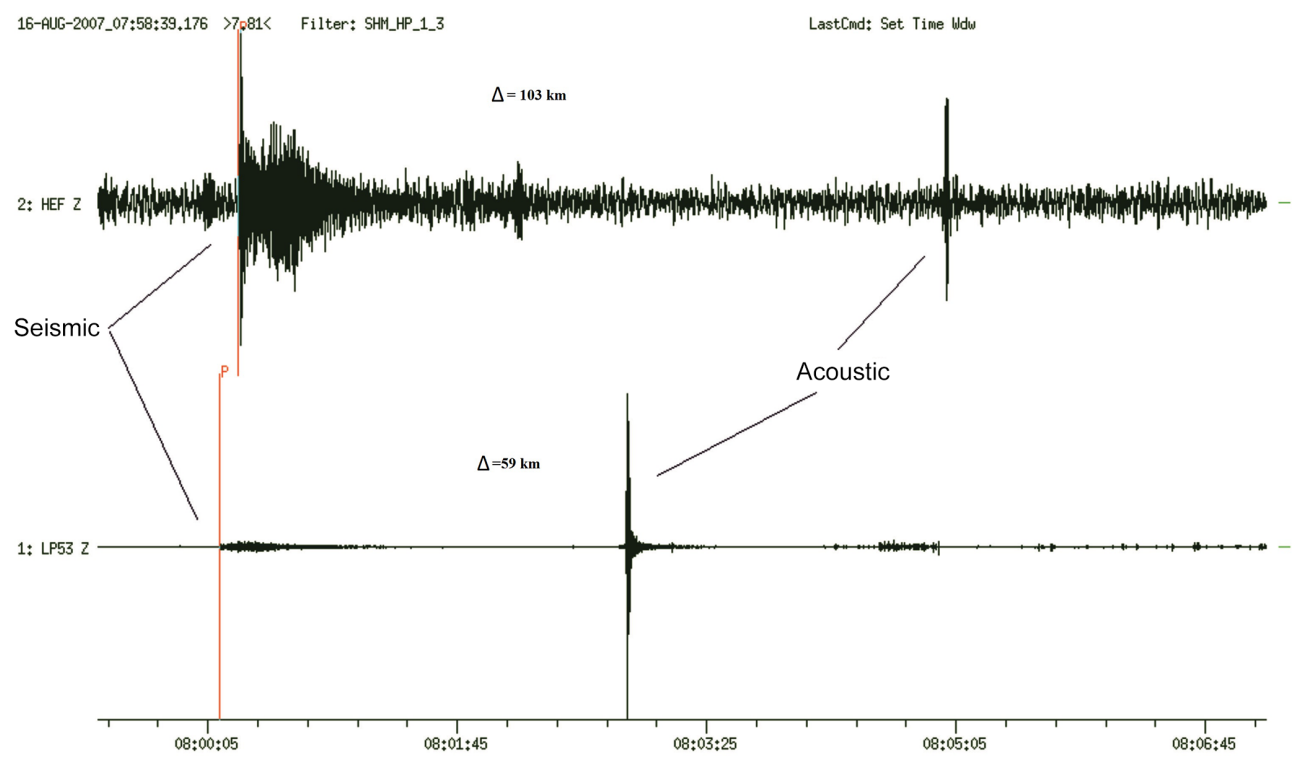

Figure 3. Seismograms of explosion on 16 August 2007 at $08: 00 \mathrm{UTC}, 67.93^{\circ} \mathrm{N}, 25.82^{\circ} \mathrm{E} \mathrm{ML}=1.5$ (FENCAT) from Hukkavaara hill. Traces are normalised to maximum amplitude.

Table 2. Results of Hukkavaara explosions location with the HYPOELLIPS method (index 1) and the grid search method (index 2). Sec1/2 is the final source time defined by HYPOELLIPS/grid search method, lat1/2 (long1/2) is the final latitude (longitude) defined by HYPOELLIPS/grid search method. Dep1/2 is the depth defined by HYPOELLIPS/grid search method, rms1 is the final HYPOELLIPS root mean square residual, rms2 is the final grid search method rms, $N$ is the number of POLENET/LAPNET stations used, $\sigma_{x}$ and $\sigma_{z}$ are the horizontal and vertical uncertainties at the $68 \%$ confidence level, $r_{\min }$ is the epicentre distance to the nearest station, $r_{\text {max }}$ is the epicentre distance to the most remote station.

\begin{tabular}{rrrrrrrrrrrrrr}
\hline yy.mm.dd & $\begin{array}{r}\text { hh:mm } \\
\text { UTC }\end{array}$ & sec1/sec2 & lat ${ }^{\circ} \mathrm{N} 1 / 2$ & long ${ }^{\circ} \mathrm{E} 1 / 2$ & $\begin{array}{r}\text { dep } \\
(\mathrm{km}) 1 / 2\end{array}$ & $\begin{array}{r}\mathrm{rms} 1 \\
(\mathrm{~s})\end{array}$ & $\begin{array}{r}\mathrm{rms} 2 \\
(\mathrm{~s})\end{array}$ & $\begin{array}{r}\text { Gap } \\
\left({ }^{\circ}\right)\end{array}$ & $\begin{array}{r}N \\
\begin{array}{r}\sigma_{x} \\
(\mathrm{~km})\end{array}\end{array}$ & $\begin{array}{r}\sigma_{z} \\
(\mathrm{~km})\end{array}$ & $\begin{array}{r}r_{\min } \\
(\mathrm{km})\end{array}$ & $\begin{array}{r}r_{\max } \\
(\mathrm{km})\end{array}$ \\
\hline 08.08 .24 & $12: 30$ & $0.9 / 0.8$ & $67.95 / 67.94$ & $25.82 / 25.83$ & $0.2 / 0.0$ & 0.13 & 0.18 & 47 & 25 & 0.3 & 0.9 & 24 & 267 \\
08.08 .29 & $11: 00$ & $0.5 / 0.4$ & $67.93 / 67.94$ & $25.83 / 25.85$ & $0.0 / 0.0$ & 0.25 & 0.23 & 47 & 23 & 0.7 & 4 & 25 & 179 \\
07.08 .16 & $08: 00$ & $0.4 / 0.4$ & $67.94 / 67.94$ & $25.82 / 25.85$ & $0.0 / 0.05$ & 0.18 & 0.13 & 117 & 7 & 0.6 & 3 & 59 & 239 \\
\hline
\end{tabular}

ence between hypocentres depths obtained by two methods is more than $8 \mathrm{~km}$ or the error for the hypocentre depth obtained by the HYPOELLIPSE is more than $8 \mathrm{~km}$. For the second group of 23 events, we obtained stable hypocentre solutions and depths of less than $20 \mathrm{~km}$. The third group consists of two events with hypocentres near the surface. Hypocentres of the fourth group of seven events have stable solutions and depth of more than $20 \mathrm{~km}$.

The comparison of hypocentre coordinates with those from the FENCAT catalogue showed that the latitude differences are less than $7 \mathrm{~km}$, while the longitude differences may reach values of $8-12 \mathrm{~km}$. The hypocentres of most of the natural events from Table 3 are deeper than the hypocentres presented in FENCAT catalogue. This difference can be explained by different velocity models used for event location, larger number of observations, station distribution and higher density of stations. In Table 3 the asterisks denote the events with one and more stations satisfying the condition $\Delta<2 \times$ dep, where $\Delta$ is an epicentral distance and dep is the hypocentre. For these events we expect more reliable determination of depth. For investigating the stability of the depth determination, we analysed the depth rms error using the grid search method. The local minimum of the depth rms error is presented in Table 3.

The comparison of the observed and theoretical travel times after relocation is shown in Fig. 4 for one selected shallow earthquake, one selected deep earthquake and the deepest earthquake from all events. As for the deepest event (Fig.4c), a possible explanation of the scatter is the difference in seismic velocities beneath different groups of stations which is not possible to take into account in a 1-D model used for relocation. This earthquake is situated near the end of the system of Palojärvi, Paatsikkajoki and Kultima faults. Analysis of seismicity map from Korja and Kosonen (2015) shows that one deep earthquake was recorded earlier along the same postglacial fault branch.

Results of focal mechanism calculations for one shallow event are presented in Table 4 and in Fig. 5. For determining 


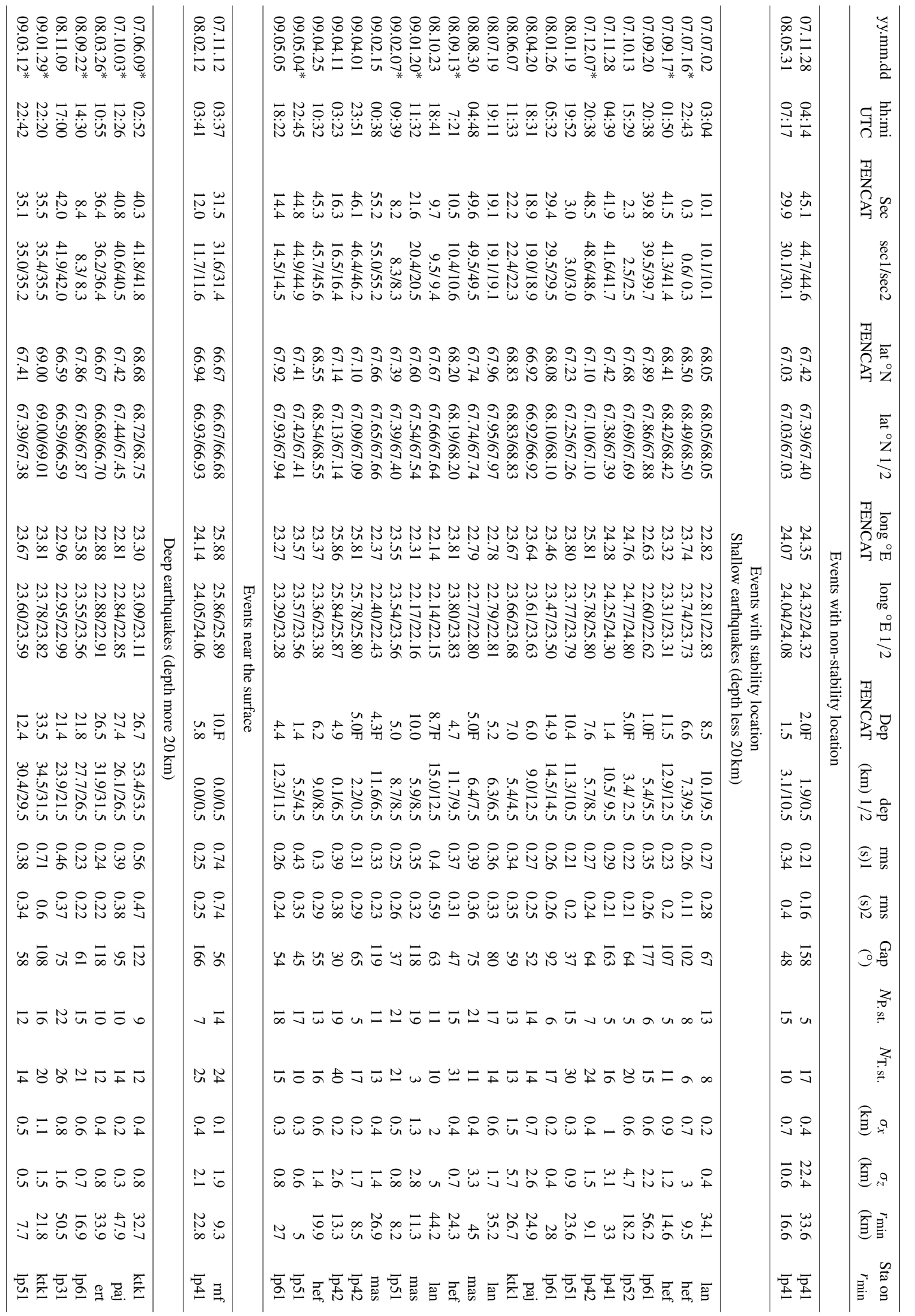

응 훙 훙

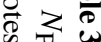
$F \div$

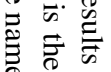
虽宫 훙 要家 胥 至 홍. $\exists$ 它 के 告 西 월 응 응 है 贯 番罂 窖 药 क 记.

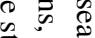
₹ 잉 说. 它 吉志 훙 중 8 的 눙 웅

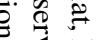

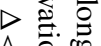
$\wedge$ ㅇ. ต़ $\times$ के 욕 \% 궁 웅 $\stackrel{6}{\circ} 0$ \% 学要 굴 항 艺究 䙵䡒 贻. $\hat{\Xi}$ \%

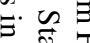
苛总罗 ㄹ. ㄹ. 

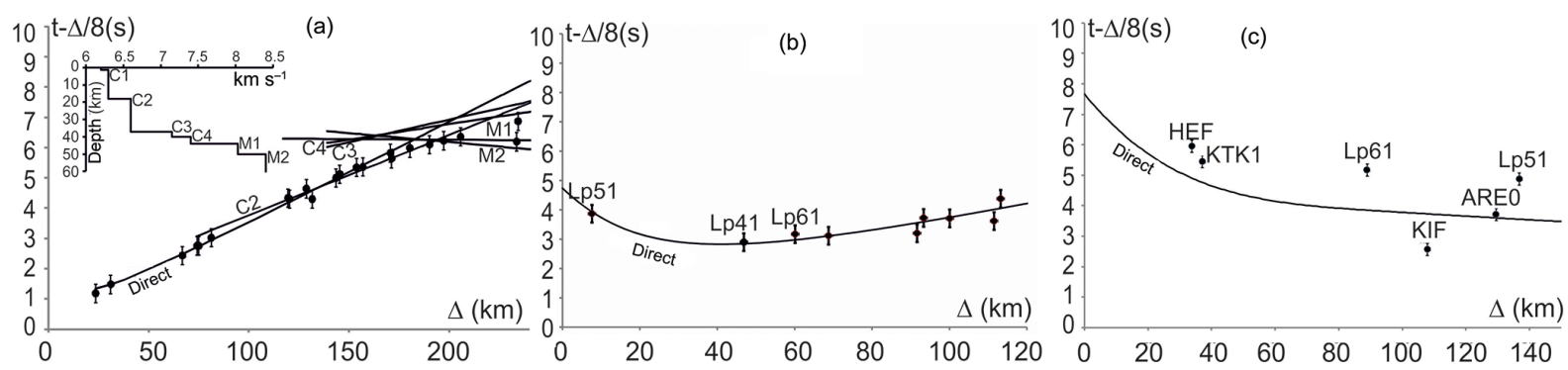

Figure 4. Result of relocation by HYPOELLIPSE: comparison of observed and calculated travel times (a) for shallow earthquake on 19 January 2008 at 19:52 UTC, $67.23^{\circ} \mathrm{N}, 23.80^{\circ} \mathrm{E}$, depth $=10.4 \mathrm{~km}, \mathrm{ML}=2.2$ (FENCAT); (b) for deep earthquake on $12 \mathrm{March} 2009$ at 22:42 UTC, $67.41^{\circ} \mathrm{N}, 23.67^{\circ} \mathrm{E}$, depth $=12.4 \mathrm{~km}, \mathrm{ML}=1.0$ (FENCAT); (c) for deep earthquake on 09 June 2007 at 02:52 UTC, $68.68^{\circ} \mathrm{N}$, $23.30^{\circ} \mathrm{E}$, depth $=26.7 \mathrm{~km}, \mathrm{ML}=1.7$ (FENCAT).

Table 4. Source parameters of the event considered in our study.

\begin{tabular}{lr}
\hline & Event 1 \\
\hline Date & 13 Sept 2008 \\
Origin time (UTC) & $07: 21: 10.6$ \\
Latitude $\left({ }^{\circ} \mathrm{N}\right)$ & 68.20 \\
Longitude $\left({ }^{\circ} \mathrm{E}\right)$ & 23.83 \\
Depth $(\mathrm{km})$ & 9.5 \\
$\mathrm{ML}$ & 1.9 \\
Strike/dip/rake $\left({ }^{\circ}\right)$ & $21 / 77 / 152$ \\
Fault plane uncertainty $\left({ }^{\circ}\right)$ & 19 \\
2 Strike/dip/rake $\left({ }^{\circ}\right)$ & $118 / 63 / 15$ \\
Auxiliary plane uncertainty $\left({ }^{\circ}\right)$ & 24 \\
$P$ axis: trend/plunge & $72 / 9$ \\
$T$ axis: trend/plunge & $336 / 29$ \\
\hline
\end{tabular}

focal mechanisms we used the program HASH (Hardebeck and Shearer, 2008), which estimates earthquake focal mechanisms from the first-motion polarities. The polarity of signals at all stations was tested using strong teleseismic events.

The data used consists of 22 first motion polarities. The stability of a focal mechanism with respect to the polarity errors was tested by a bootstrap procedure, that is, by removing single polarity data points in sequence and observing the change in the best-fitting mechanism. The stability with respect to different velocity models was controlled using velocity models from different studies (Silvennoinen et al., 2010; Janik et al., 2009; Silvennoinen et al., 2014). The tests confirmed the stability of solution. The focal mechanism is of oblique type with strike-slip prevailing.

\section{Local events tomography}

Local event tomography was used for estimating the $P$ wave velocity structure in the upper crust of our study region. The procedure consists of two steps. The first one is an improvement of the a priori 1-D model (Table 1), calculating station corrections and relocating the events in the new 1-D model

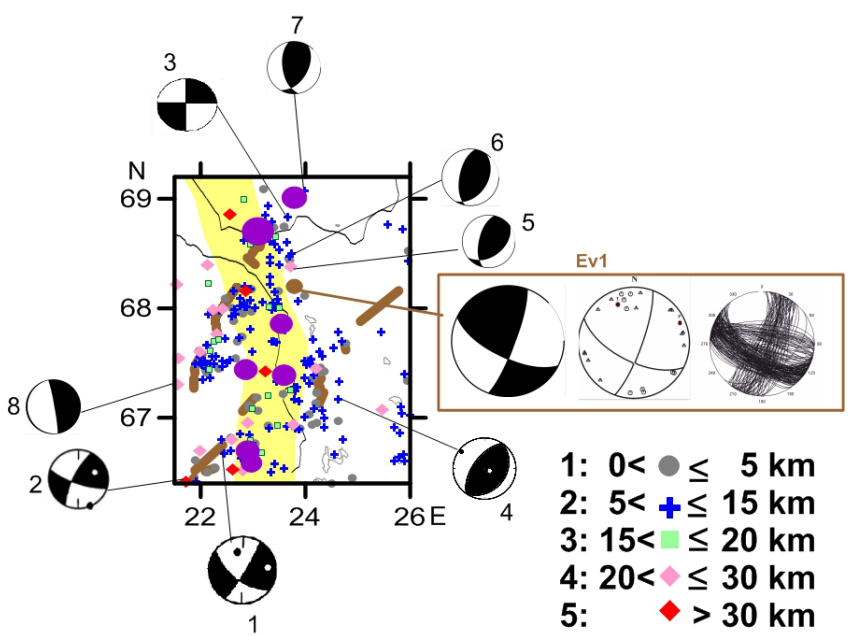

Figure 5. Local earthquakes from catalogue FENCAT in the period with 1964 to 2008 years and available fault plane solutions for some earthquakes in the Region 2 . The earthquakes are divided into five groups depending on hypocentre depth. The number of earthquakes equals 55 in Group 1, 126 in Group 2, 17 in Group 3, 21 in Group 4, and 5 in Group 5. Deep earthquakes with reliable location from Table 3 are shown by purple circles. Event for which we calculated focal mechanism (Table 4) is indicated by brown circles. In the brown frame left: lower hemisphere equal area projections of the focal sphere, middle: octagons and triangles represent compressions and dilatations, right: the set of 150 acceptable mechanisms for demonstration of uncertainty range. Brown lines are denoting postglacial faults. Baltic-Bothnia Megashear (BBMS) from (Berthelsen and Marker, 1986) is shown by yellow stripe.

using the program VELEST (a computer program for deriving 1-D velocity models for earthquake location procedures and as initial reference models; Kissling, 1988; Kissling et al., 1994) and the known hypocentre parameters. The second part incorporates consecutive inversion for the 3-D velocity model and hypocentre coordinates using the SIMULSPS14 program (Thurber, 1983; Eberhart-Phillips, 1993; Thurber, 1993). In this code the ray tracing is performed with the 


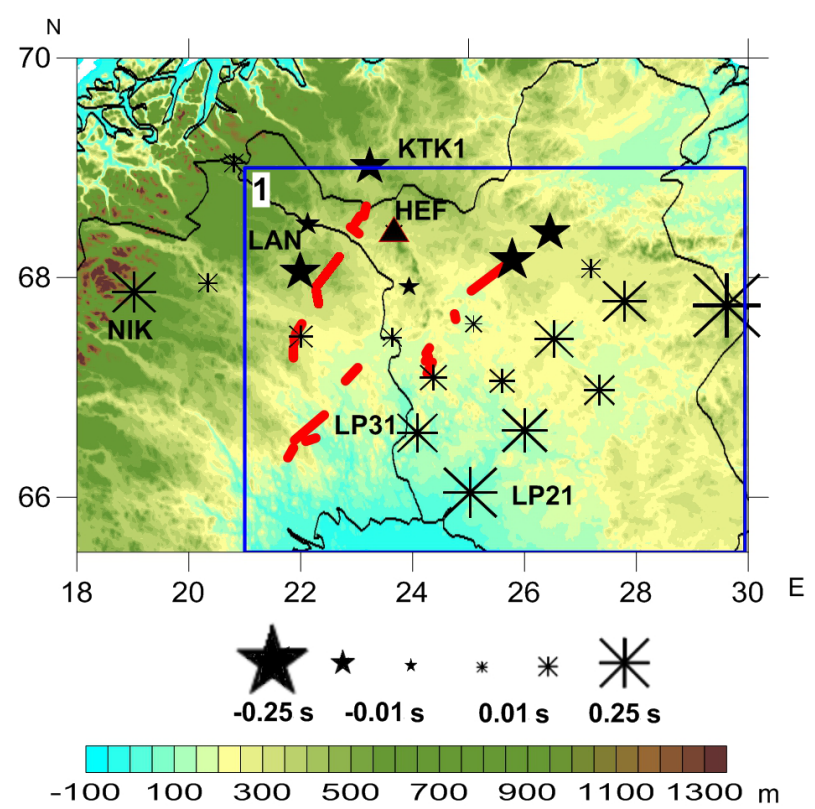

Figure 6. The time station corrections imposed on a topographic map ETOPO1 (Amante and Eakins, 2009) and computed with respect to the reference station HEF by VELEST. Stars denote negative corrections, snowflakes denote positive corrections. The size of the symbol (star or snowflake) is proportional to the value of correction. The red lines denote postglacial faults. Blue box indicates Region 1. The full names of faults are the same as in Fig. $1 \mathrm{~b}$.

shooting method by Virieux et al. (1988), where the rayconnecting station and receiver in the given velocity model are found by varying the initial azimuth and incidence angle at the source. The 3-D velocity model is parameterised by a regular grid and the velocity model is described by linear B splines. The velocity inversion is performed using a damped least-squares method and resolution matrix is estimated simultaneously. The calculations were performed with both synthetic and real data.

As a starting model, we used the velocity model from Table 1. The VELEST was run with a total of $36 \times 4+9+50+2=205$ unknowns and 624 rays: 311 direct and 313 refracted. The overdetermination factor of the inverse problem is approximately 3 . The maximum number of hypocentres (25) is located at depths from 1.3 to $18 \mathrm{~km}$. The number of observations for each station varies from 1 to 37. The rms residuals for all events are decreased by $8 \%$ after the third iteration. The velocities were modified only in the layers between 1.3 and $18 \mathrm{~km}$ and between 18 and $37 \mathrm{~km}$. Final velocity values in these layers have changed by less than $0.1 \mathrm{~km} \mathrm{~s}^{-1}$ compared to the initial values. After the third iteration the relocated hypocentre parameters differed from the initial ones by less than $2.3 \mathrm{~km}$ in horizontal direction and less than $1.5 \mathrm{~km}$ in vertical direction.

According to Kissling (1988), the station corrections should reflect the basic features of surface geology. Only the
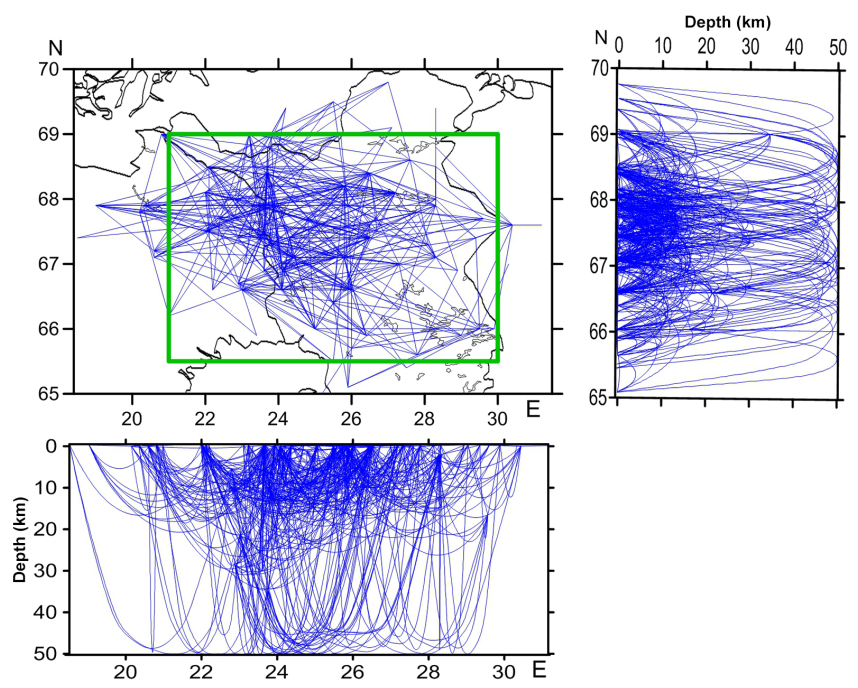

Figure 7. The ray coverage of the area in the horizontal and two vertical planes.

corrections for stations with many observations in different azimuth directions may be accounted for by lateral variations in the shallow subsurface, however. The station corrections used in inverse problem are shown separately in Fig. 6 for the stations that registered more than 10 observations of the first arrival of $P$ wave. The maximum number of arrivals was observed at the permanent station HEF. That is why it was selected as a reference station. As seen from Fig. 6, the negative time corrections prevail in the northern part of the area, while in the south-east the positive time corrections are observed. The corrections that are probably linked to the superficial geology were obtained, for example, for stations KTK1 (elevation $365 \mathrm{~m}$, negative), LAN (elevation $500 \mathrm{~m}$, negative), LP21 (elevation $94 \mathrm{~m}$, positive) and LP31 (elevation $139 \mathrm{~m}$, positive). The correction for the NIK (Nikkaluokta) station is connected to the edge effects, because this station is situated near the western boundary of the studied region. It has an elevation of $300 \mathrm{~m}$ and simultaneously a large positive correction.

SIMULPS14 was run with $36 \times 4+9=153$ hypocentre variables, 299 velocity adjustments and 621 times of the first $P$ arrivals. The overdetermination factor was 1.6. This is a low value, but it is sufficient to determine large-scale velocity heterogeneities in our study area, assuming that the ray coverage and resolution tests are in order. The ray coverage is presented in Fig. 7. The high ray density is observed at the depths of $0-20 \mathrm{~km}$. In the present study, the distance between adjacent grid nodes equals $70 \mathrm{~km}$ in an $x$ direction and $50 \mathrm{~km}$ in a $y$ direction.

The resolution was analysed through several checkerboard tests. The synthetic checkerboard velocity model was calculated by varying the velocity as a sinusoidal function in the $x$ and $y$ directions. The maximum amplitude of positive and negative velocity perturbations was $6 \%$ with respect to a 

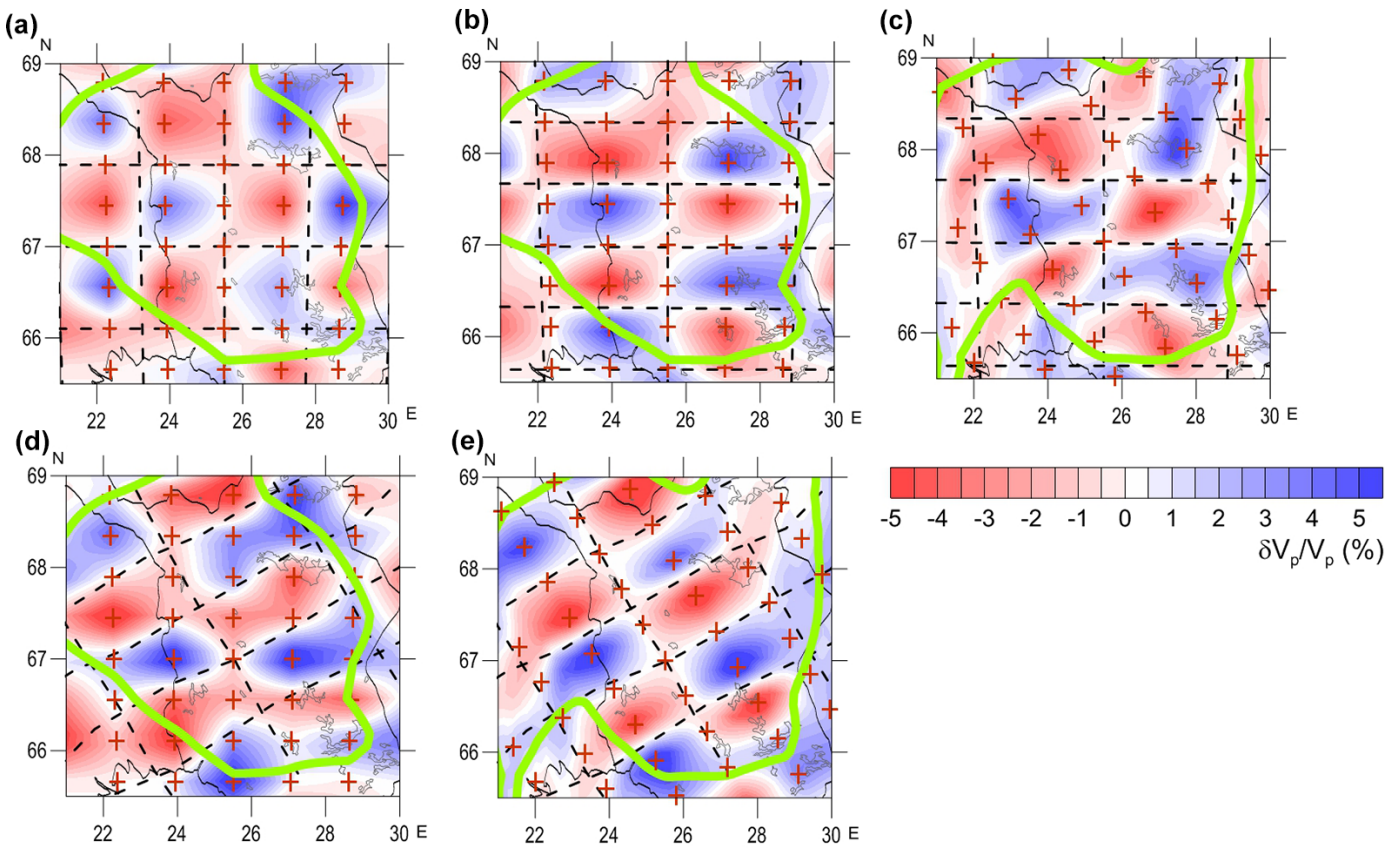

Figure 8. Results of the checkerboard test for normal orientation of synthetic anomalies and normal grid with different sizes of synthetic anomalies: (a) $100 \times 100 \mathrm{~km}$, (b) $150 \times 75 \mathrm{~km}$. Subplots (c), (d) and (e) show results of testing for size $150 \times 75 \mathrm{~km}$. (c) Orientation of synthetic anomalies is normal (W-E oriented), the inversion grid is rotated to an angle of $30^{\circ}$ anticlockwise from the north, (d) synthetic anomalies are rotated, orientation of the inversion grid is normal, (e) both synthetic anomalies and the grid are rotated. Horizontal cross sections of the reconstructed pattern are shown for the depth of $10 \mathrm{~km}$. The dotted lines are the boundaries of synthetic anomalies with different velocity in testing model. Green contours restrict the area with a resolution of more than 0.5. Brown crosses denote locations of the parameterisation nodes for the inversion grid.

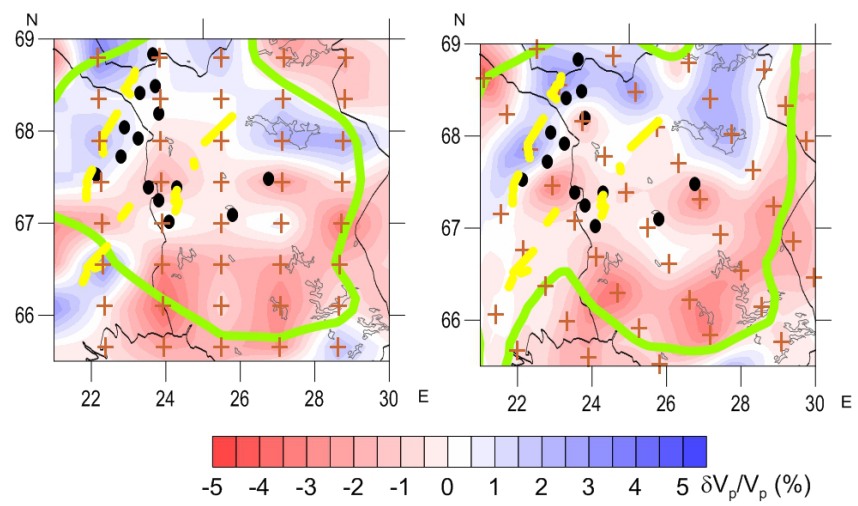

Figure 9. Horizontal cross sections of 3-D velocity structure reconstructed with the SIMULPS14 for the depth of $10 \mathrm{~km}$ and Region 1. Left subplot shows the result for normal inversion grid and right subplot shows the result for the inversion grid which is rotated to an angle of $30^{\circ}$ anticlockwise from the north. Green contours restrict the area with resolution more than 0.5. Yellow lines denote postglacial faults (detailed description is presented in Fig. 1). Black points show hypocentres of the earthquakes relocated in the 3-D model for which $6 \leq$ depths $<14 \mathrm{~km}$.

background velocity model (Table 1 ). We perform synthetic tests with the cells of $100 \times 100$ and $150 \times 75 \mathrm{~km}$ (Fig. 8).
We obtained the alternation of positive and negative anomalies for the grid with $100 \times 100 \mathrm{~km}$ cells and for the grid with $150 \times 75 \mathrm{~km}$ cells. The tests were also performed to analyse the reconstruction picture with normal grid orientation and the grid rotated by $30^{\circ}$. Comparison of Fig. $8 \mathrm{~b}$ and $\mathrm{c}$ shows that the shape of the anomalies recovered (especially of high-velocity anomalies) depends on grid orientation. The true boundary of a discontinuity is determined better when it coincides with the grid line (Fig. 8b, e).

Results of inversion with real data and with different grids are presented in Fig. 9, in which the horizontal cross sections of the final velocity model are shown for $10 \mathrm{~km}$ depth. The deviations of $P$ wave velocities from the 1-D background velocity model (Table 1 ) do not exceed $\pm 5 \%$. The rms misfit decreased from 0.32 to $0.27 \mathrm{~s}$ for the normally oriented grid and from 0.32 to $0.25 \mathrm{~s}$ in the rotated grid. After relocation by SIMULPS14, the maximum vertical deviation of event hypocentres equals $5 \mathrm{~km}$ and the maximum horizontal deviation equals $3 \mathrm{~km}$. The final $3-\mathrm{D}$ velocity model was obtained after averaging two models derived using two different grids: one with normal orientation and one rotated to an angle of $30^{\circ}$ anticlockwise from the north. It is presented in Fig. 10. One can see a high-velocity zone in the northern part of the study area that continues to a depth of about $10 \mathrm{~km}$. High velocities are observed to the west of $24^{\circ} \mathrm{E}$, while low 


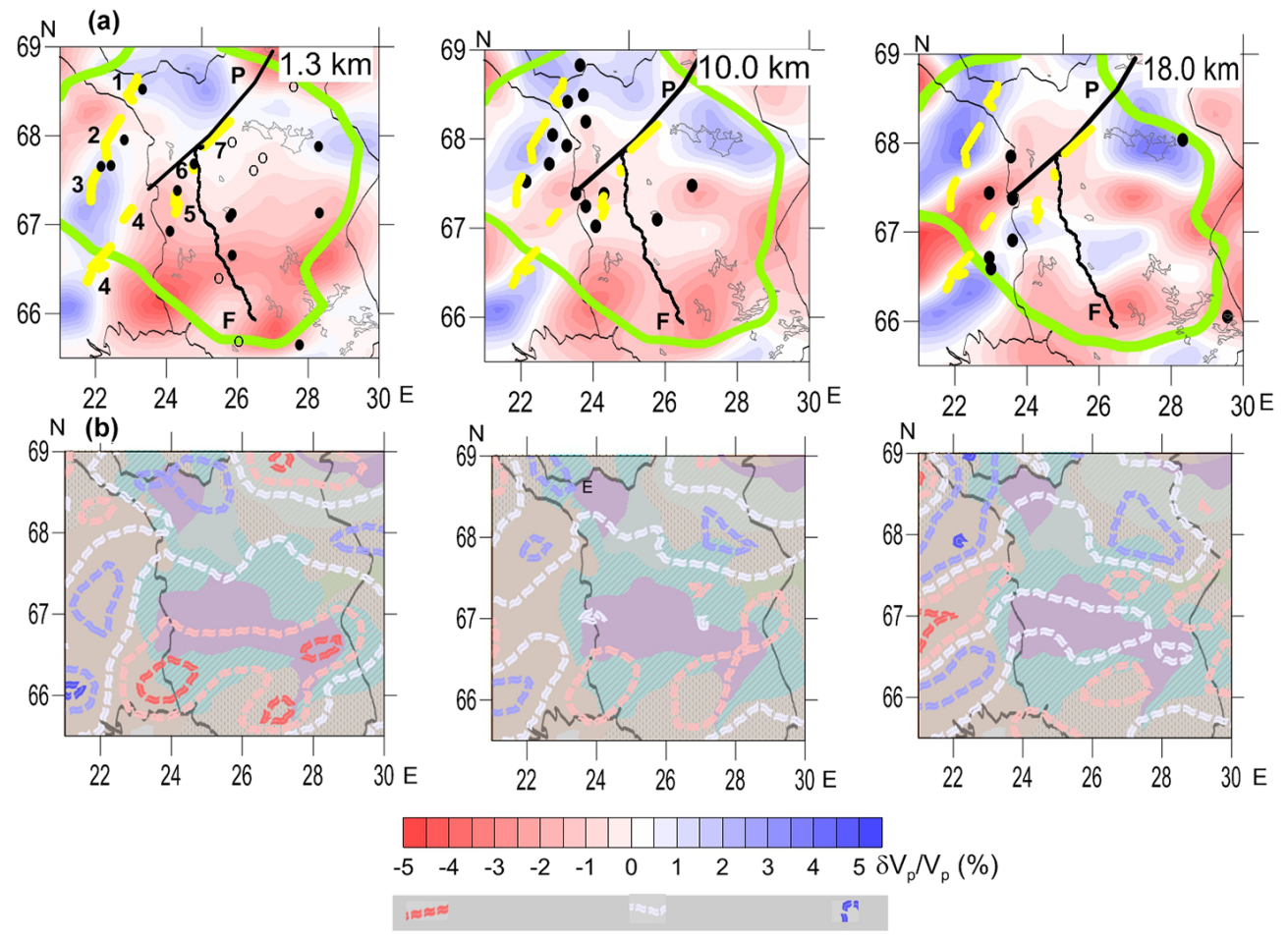

Figure 10. Upper crustal 3-D velocity structure of Region 1 reconstructed with SIMULPS14 and appropriate isolines of velocity anomalies on the background of the geological map. Horizontal cross sections are shown for depths of 1.3, 10.0, and $18.0 \mathrm{~km}$ after averaging two results derived from two different grids: one with normal orientation and one rotated to an angle of $30^{\circ}$ anticlockwise from the north. Green contours restrict the area with average resolution more than 0.5. Yellow lines denote postglacial faults (detailed description is presented in Fig. 1). Black lines denote position of the profiles: FIRE with the letter F, POLAR with the letter P. Black points show hypocentres of the earthquakes relocated in the 3-D model. In the section corresponding to $1.8 \mathrm{~km}$, we show earthquakes with depths $<6 \mathrm{~km}$; in the section corresponding to $10 \mathrm{~km}$ we show earthquakes for which $6 \leq$ depths $<14 \mathrm{~km}$; in the section for $18 \mathrm{~km}$, we show the earthquakes with depths $\geq 14 \mathrm{~km}$. Black blank circles are the explosions shown in the section of $1.8 \mathrm{~km}$.

velocities prevail to the east of it. The elongated low-velocity area stretching NE-SW is seen in the western part of region around $67^{\circ} \mathrm{N}$. This area becomes more visible with depth.

\section{Discussion and conclusions}

In spite of low seismic activity during the POLENET/LAPNET data acquisition period, it was possible to obtain accurate and reliable coordinates of hypocentres for a number of local earthquakes and to calculate one focal mechanism. We also reconstructed a 3-D $P$ wave velocity model of the upper crust to a depth of about $18 \mathrm{~km}$ for the area that has not been studied previously using seismic tomography techniques. Recently, local seismic tomography research was performed for other areas in northern Fennoscandia (Lindblom et al., 2015). Lindblom et al. (2015) concentrated on the relocation and optimal average 1-D model, while the 3-D velocity model was not discussed in details. In the present study, the 3-D velocity structure is of primary interest. Generally, our results provide new knowledge about the structures along which the intraplate seismicity in the northern part of the Fennoscandian Shield is concentrated.

As seen from Fig. 10, the $P$ wave velocity anomalies in the area with high resolution are smaller than $\pm 5 \%$ with respect to the initial velocity model. The lateral heterogeneities in the upper crust of our velocity model show general good correlation with the surface geology and are in agreement with the 3-D $S$ wave velocity model obtained by Poli et al. (2013) by ambient noise tomography as well as with the 2-D $P$ and $S$ wave velocity models along the POLAR profile (Janik et al., 2009) and with the $P$ wave velocity model along the southern segment of the FIRE4 profile (Silvennoinen et al., 2010). The high-velocity anomaly correlates partly with the $2.1 \mathrm{Ga}$ Greenstones area and partly with the Lapland Granulite Terrane (Fig. 1). These units correspond to the high $P$ and $S$ wave velocity zones in the upper crust in the model by Janik et al. (2009). Poli et al. (2013) also detected the high $S$ wave velocity anomaly corresponding to this unit.

The low-velocity anomaly in the southern part of our study area is observed in the range of depths from 0 to $5 \mathrm{~km}$ and disappears at a depth of $10 \mathrm{~km}$ (Fig. 10). This anomaly correlates with the southern part of the Lapland Granitoid com- 
Table 5. Information about focal mechanisms of local earthquakes for Region 2 from other sources.

\begin{tabular}{lllrrrrrll}
\hline No. & Data & Ml & Depth & Lat & Long & Strike & Dip & Rake & Source \\
\hline 1 & $1987 / 05 / 27$ & 2.0 & 14.0 & 66.64 & 22.37 & 30 & 80 & 34 & Arvidsson (1996) \\
2 & $1987 / 07 / 18$ & 2.4 & 34.0 & 66.42 & 21.71 & 205 & 70 & 20 & Arvidsson (1996) \\
3 & $1989 / 11 / 16$ & 1.6 & 12.5 & 68.83 & 23.67 & 0 & 90 & 0 & Bungum and Lindholm (1996) \\
4 & $2001 / 05 / 02$ & 2.9 & 5.0 & 67.16 & 24.59 & 35 & 30 & 90 & Uski et al. (2003) \\
5 & $2007 / 01 / 16$ & 1.5 & 21.9 & 68.38 & 23.73 & 193 & 57 & 66 & Uski and Korja (2007) \\
6 & $2007 / 02 / 25$ & 1.3 & 8.6 & 68.47 & 23.69 & 191 & 56 & 78 & Uski and Korja (2007) \\
7 & $1991 / 04 / 13$ & 2.6 & 10.0 & 69.12 & 24.05 & 30 & 45 & 120 & Bungum and Lindholm (1996) \\
8 & $1975 / 08 / 11$ & 3.9 & & 67.4 & 21.76 & 350 & 85 & -90 & Arvidsson and Kulhanek (1994) \\
\hline
\end{tabular}

plex (LGC) and Peräpohja Schist belt (Fig. 1). The LGC is also seen as a low $S$ wave velocity anomaly in the model by Poli et al. (2013). Silvennoinen et al. (2010) calculated a high-resolution $P$ wave tomographic velocity model and discovered a highly reflective high-velocity and high-density body beneath the LGC with the upper boundary at a depth of $1-3 \mathrm{~km}$. This feature, revealed by high-resolution seismic survey, is not seen in our model and was parameterised with large blocks. The low-velocity anomaly located approximately at the Finnish-Swedish border at a depth of $18 \mathrm{~km}$ does not correlate with any geological unit and might be an inversion artefact.

A comparison of velocity anomalies revealed by seismic tomography (Fig. 10) with the position of earthquake hypocentres and postglacial faults suggests that seismogenic structures in our study region do not correlate with the boundaries of geological units formed in Archaean and during their subsequent reactivation in Proterozoic. However, they show good correlation with known postglacial faults in the region, which also agrees with the results obtained by Lindblom et al. (2015). These postglacial faults are generally located within a broad $\mathrm{N}-\mathrm{S}$-directed zone running from the Bothnian Bay to the Atlantic Ocean. This zone coincides with the old Precambrian Baltic-Bothnia Megashear zone (BBMS) (Berthelsen and Marker, 1986), interpreted in Lahtinen et al. (2005) as an old plate boundary.

Van Lanen and Mooney (2007) proposed that such ancient suture zones have a high probability of reactivation. They also showed that the existence of deeply penetrating crustal faults is the major parameter that controls distribution of intraplate earthquakes in the stable continental region of North America. The deepest earthquakes in our study area are shown in Fig. 5. They are located along the BBMS, although not all of them can be associated with known postglacial faults. According to Arvidsson (1996), the deepest earthquakes from the Lansjärv fault and the Lainio-Suijavaara fault have focal depths of 34 and $37 \mathrm{~km}$ respectively. In our research the seismic events at Lansjärv and Lainio-Suljavaara faults located in the BBMS area have hypocentre depths up to $20 \mathrm{~km}$. The deep earthquakes have also been detected on other postglacial faults (Lindblom et al., 2015; Juhlin and Lund, 2011).

Figure 5 summarises the available fault plane solutions for the earthquakes in the area of BBMS. Information on the sources of these earthquakes is presented in Table 4 (our study) and Table 5 (previous studies). As seen, the focal mechanisms are of different types, although Arvidsson (1996) interpreted most of the northern Fennoscandian postglacial earthquakes as signatures of a progressive rapid rise of the land from the centre of postglacial rebound (Nocque et al., 2005). The world stress map 2008 (http://dc-app3-14.gfz-potsdam.de/ pub/stress_maps/stress_maps.html) also shows four thrustfaulting stress indicators in northern Fennoscandia, which are typical for the process of rebound.

Recently, Steffen et al. (2014) showed that the depth of the fault tip and angle of the fault play an important role in the reactivation of faults by deglaciation processes. They find that steeply dipping faults $\left(\sim 75^{\circ}\right)$ can be activated after glacial unloading if the assumed coefficient of friction in the rock is low, and fault activity continues thereafter. This agrees with the results of our study that show that seismicity in the BBMS occurs at the steeply dipping faults penetrating to a depth of $30 \mathrm{~km}$. This also can be a possible explanation for why this activity continues nowadays. It should be noted that the model events in the study by Steffen et al. (2014) have the reverse faulting mechanisms, not the strike-slip ones considered in our study.

Generally, our study shows that the BBMS is an important reactivated large-scale tectonic suture in the northern Fennoscandian Shield that extends to greater depths. This is necessary to take into account when estimating seismic hazard in the area.

\section{Data availability}

Continuous data from the POLENET/LAPNET temporary seismic array available from http://eida.gfz-potsdam.de/ webdc3/index.html. 


\section{The Supplement related to this article is available online at doi:10.5194/se-7-1095-2016-supplement.}

Acknowledgements. The authors appreciate the efforts of organisations operating permanent seismograph networks of Finland (the Institute of Seismology of the University of Helsinki and Sodankylä Geophysical Observatory of the University of Oulu) and the Swedish National Seismic Network in Uppsala, which contribute to data for the FENCAT catalogue. The POLENET/LAPNET project was a part of the International Polar Year 2007-2009. Equipment for the temporary deployment was provided by RESIF-SISMOB, FOSFORE, EOST-IPG Strasbourg Equipe seismologie (France), Seismic pool (MOBNET) of the Geophysical Institute of the Czech Academy of Sciences (Czech Republic), the Sodankylä Geophysical Observatory (Finland), the Institute of Geosphere Dynamics of RAS (Russia), the Institute of Geophysics ETH Zürich (Switzerland), the Institute of Geodesy and Geophysics, the Vienna University of Technology (Austria) and the University of Leeds (UK). Funding agencies which provided support for the organisation of the experiment are Finland: the Academy of Finland (grant no. 122762) and University of Oulu, France: BEGDY programme of the Agence Nationale de la Recherche, Institute Paul Emil Victor and ILP (International Lithosphere Programme) Task Force VIII, Czech Republic: grant no. IAA300120709 of the Grant Agency of the Czech Academy of Sciences. Russian Federation: Russian Academy of Sciences (programmes no. 5 and no. 9).

The POLENET/LAPNET working group members are Elena Kozlovskaya, Helle Pedersen, Jaroslava Plomerová, Ulrich Achauer, Eduard Kissling, Irina Sanina, Teppo Jämsén, Hanna Silvennoinen, Catherine Pequegnat, Riitta Hurskainen, Robert Guiguet, Helmut Hausmann, Petr Jedlicka, Igor Aleshin, Ekaterina Bourova, Reynir Bodvarsson, Evald Brückl, Tuna Eken, Pekka Heikkinen, Gregory Houseman, Helge Johnsen, Elena Kremenetskaya, Kari Komminaho, Helena Munzarova, Roland Roberts, Bohuslav Ruzek, Hossein Shomali, Johannes Schweitzer, Artem Shaumyan, Ludek Vecsey and Sergei Volosov. We thank the anonymous reviewers for valuable comments that helped us to improve the manuscript.

Edited by: I. Koulakov

Reviewed by: two anonymous referees

\section{References}

Amante, C. and Eakins, B. W.: ETOPO1 1 Arc-Minute Global Relief Model: Procedures, Data Sources and Analysis, NOAA Technical Memorandum NESDIS NGDC-24, National Geophysical Data Center, NOAA, doi:10.7289/V5C8276M, 2009.

Arvidsson, R.: Fennoscandian Earthquakes: Whole Crustal Rupturing Related to Postglacial Rebound, Science, 274, 5288, 744746, 1996

Arvidsson, R., Wahlstrom, R., and Kulhanek, O.: Deep-crustal earthquakes in the southern Baltic Shield, Geophys. J. Int., 108, 767-777, 1992.
Berthelsen, A. and Marker, M.,: 1.9-1.8 Ga old strike-slip megashears in the Baltic Shield, and their plate tectonic interpretation, Tectonophysics, 128, 163-181, 1986.

Bruneton, M., Pedersen, H. A., Farra R., Arndt N. T., Vacher P., Achauer U., Alinaghi A., Ansorge J., Bock, G., Friederich, W., Grad, M., Guterch, A., Heikkinen, P., Hjelt, S. E., Hyvonen, T. L., Ikonen J. P., Kissling, E., Komminaho, K., Korja A., Kozlovskaya, E., Nevsky, M. V., Paulssen, H., Pavlenkova, N. I., Plomerova J., Raita, T., Riznichenko, O. Y., Roberts, R. G., Sandoval, S.,. Sanina I. A., Sharov, N. V., Shomali, Z. H., Tiikainen, J., Wieland, E., Wylegalla, K., Yliniemi, J., and Yurov, Y. G.: Complex lithospheric structure under the central Baltic Shield from surface wave tomography, J. Geophys. Res., 109, B10303, doi:10.1029/2003JB002947, 2004.

Bungum, H. and Lindholm, C.: Seismo- and neotectonics in Finnmark, Kola and the southern Barents Sea, part 2: Seismological analysis and seismotectonics, Tectonophysics, 270, 15-28, 1996.

Bungum, H., Olesen, O., Pascal, C., Gibbons, S., Lindholm, C., and Vestøl, O.: To what extent is the present seismicity of Norway driven by post-glacial rebound?, J. Geol. Soc., 167, 373-384, 2010.

Daly, J. S., Balagansky, V. V., Timmerman, M. J., and Whitehouse, M. J.: The Lapland-Kola orogen: Palaeoproterozoic collision and accretion of the northern Fennoscandian lithosphere, in: European Lithosphere Dynamics, edited by: Gee, D. G. and Stephenson, R. A., Geol. Soc. London, Mem. Ser., 32, 579-598, 2006

Eberhart-Phillips, D.: Local earthquake tomography: earthquake source regions, in: Seismic Tomography: Theory and Practice, edited by: Iyer, H. M. and Hirahara, K., 1993.

Eken, T., Shomali, Z. H., Roberts, R., and Bödvarsson, R.. Uppermantle structure of the Baltic Shield below the Swedish National Seismological Network (SNSN) resolved by teleseismic tomography, Geophys. J. Int., 169, 617-630, 2007.

Glaznev, V. N.: Complex geophysical models of the Fennoscandian lithosphere, Apatity, 252 pp., 2003 (in Russian).

Guggisberg, B.: Eine zweidimensionale refraktionsseismiche interpretation der geschwindigkeits-tiefen-struktur des oberen erdmantels unter dem Fennoskandischen Schild (projekt FENNOLORA), Ph.D. thesis, Eidg. Techn. Hochsch, Zurich, Zurich, Switzerland, 1986.

Guggisberg, B., Kaminski, W., and Prodehl, C.: Crustal structure of the Fennoscandian Shield: A traveltime interpretation of the long-range FENNOLORA seismic refraction profile, Tectonophysics, 195, 105-137, 1991.

Hardebeck, J. L. and Shearer, P. M.: HASH: A FORTRAN Program for Computing Earthquake First-Motion Focal Mechanisms v1.2 - 31 January, 17 pp., http://quake.wr.usgs.gov/research/ software/\#HASH, 2008.

Hauser, F. and Stangl, R.: The structure of the crust and the lithosphere in Fennoscandia derived from a joint interpretation of $\mathrm{P}$ and $S$ wave data of the FENNOLORA refraction seismic profile, in: Sixth EGT Workshop: Data Compilation and Synoptic Interpretation, edited by: Freeman, R. and Mueller, S., Eur. Sci Found., Strasbourg, France, 71-92, 1990.

Hess, H. H.: History of Ocean Basins, in: Petrologic studies: a volume in honor of A. F. Buddington, edited by: Engel, A. E. J., James, H. L., and Leonard, B. F., Boulder, CO, Geological Society of America, 599-620, 1962. 
Hjelt, S.-E., Korja, T., Kozlovskaya, E., Lahti, I., Yliniemi, J., and BEAR and SVEKALAPKO Working Groups: Electrical conductivity and seismic velocity structures of the lithosphere beneath the Fennoscandian Shield, in: European Lithosphere Dynamics, edited by: Gee, D. and Stephenson, R., Geol. Soc. London, Mem. Ser., 32, 541-559, 2006.

Janik, T., Kozlovskaya, E., Heikkinen, P., Yliniemi, J., and Silvennoinen, H.: Evidence for preservation of crustal root beneath the Proterozoic Lapland-Kola orogen (northern Fennoscandian shield) derived from $\mathrm{P}$ and $\mathrm{S}$ wave velocity models of POLAR and HUKKA wide-angle reflection and refraction profiles and FIRE4 reflection transect, J. Geophys. Res., 114, B06308, doi:10.1029/2008JB005689, 2009.

Juhlin, C. and Lund, B.: Reflection seismic studies over the endglacial Burtrask fault, Skelleftea, Sweden, Solid Earth, 2, 9-16, doi:10.5194/se-2-9-2011, 2011.

Kissling, E.: Geotomography with Local Earthquake Data, Rev. Geophys., 26, 659-698, 1988.

Kissling, E., Ellsworth, W. L., Eberhart-Phillips, D., and Kradolfer, U.: Initial Reference Models in Local Earthquake Ttomography, J. Geophys. Res., 99, 635-646, 1994.

Koistinen, T., Stephens, M. B., Bogatchev, V., Nordgulen, Ø., Wennerström, M., and Korhonen, J.: Geological map of Fennoscandian shield, scale $1: 2000000$, Geological Surveys of Finland, Norway and Sweden and the North-West Department of Natural Resources of Russia, 2001.

Kuivamäki, A., Vuorela, P., and Paananen, M.: Indications of postglacial and recent bedrock movements in Finland and Russian Karelia, Geological Survey of Finland, Report YST-99, 92 pp., 1998

Kukkonen, I. T., Heikkinen, P., Ekdahl, E., Hjelt, S.-E., Yliniemi, J., Jalkanen, E., and FIRE Working Group: Acquisition and geophysical characteristics of reflection seismic data on FIRE transects, Fennoscandian Shield, in: Finnish Reflection Experiment (FIRE) 2001-2005, edited by: Kukkonen, I. T. and Lahtinen, R., Geol. Surv. Finland, Espoo, Finland, 13-44, 2006.

Korja, A. and Kosonen, E. (Eds): Seismotectonic framework and seismic source area models in Fennoscandia, northern Europe, Report S-63, Institute of Seismology, University of Helsinki, 285 pp., 2015

Lagerbäck, R. and Sundh, M.. Early Holocene faulting and paleoseismicity in northen Sweden, Swedish Geological Survey, Research Paper C 836, 80 pp., 2008

Lahr, J. C.: HYPOELLIPSE/Version 2.0: A computer program for determining local earthquake hypocentral parameters, magnitude, and first motion pattern, US Geological Survey Open-File Report 89-116, 92 pp., 1989.

Lahtinen, R., Korja, A., and Nironen, M.: Paleoproterozoic tectonic evolution in: Precambrian Geology of Finland - Key to the Evolution of the Fennoscandian Shield, edited by: Lehtinen, M., Nurmi, P. A., and Ramo, O. T., Elsevier Science, Amsterdam, 481-531, 2005.

Lahtinen, R., Garde, A. A., and Melezhik, V. A.: Paleoproterozoic tectonic evolution of Fennoscandia and Greenland, Episodes, 31, $1-9,2008$.

Lidberg, M., Johansson, J. M., Scherneck, H.-G., and Milne, G. A.: Recent results based on continuous GPS observations of the GIA process in Fennoscandia from BIFROST, Journal of Geodynamics, Elsevier, 50, 8 pp., 2010.
Lindblom, E., Lund, B., Tryggvason, A., Uski, M., Bödvarsson, R., Juhlin, C., and Roberts, R.: Microearthquakes illuminate the deep structure of the endglacial Pärvie fault, northern Sweden, Geophys. J. Int., 201, 1704-1716, 2015.

Luosto, U., Flueh, E. R., Lund, C.-E., and Working Group: The crustal structure along the POLAR Profile from seismic refraction investigation, Tectonophysics, 162, 51-85, 1989.

Majdanski, M., Kozlovskaya, E., and Grad, M.: 3-D structure of the Earth's crust beneath the northern part of the Bohemian Massif, Tectonophysics, 438, 57-77, 2007.

Mikko, H., Smith, C. A., Lund, B., Ask, M. V. S., and Munier, R.: LiDAR-derived inventory of post-glacial fault scarps in Sweden, GFF, doi:10.1080/11035897.2015.1036360, 2015.

Nelson, G. D. and Vidale, J. E.: Earthquake locations by 3-d finitedifference travel times, Bull. Seis. Soc. Am., 80, 395-410, 1990.

Olesen, O., Blikra, L. H., Braathen, A., Dehls, J. F., Olsen, L., Rise, L., Roberts, D., Riis, F., Faleide, J. I., and Anda, E.: Neotectonic deformation in Norway and its implications: a review, Norwegian, J. Geol., 84, 3-34, 2004.

Olsson, S., Roberts, R., and Bödvarsson, R.: Moho depth variation in the Baltic Shield from analysis of converted waves, GFF, 130, 113-122, 2008.

Pavlenkova, N. I.: Lithospheric structure of the Baltic shield from DSS data, in Structure and dynamics of the lithosphere of Eastern Europe, Geokart, Geos, Moscow, Russia, 33-58, 2006.

Plomerová, J., Vecsey, L., Babuška, V., and LAPNET Working Group: Domains of Archean mantle lithosphere deciphered by seismic anisotropy - inferences from the LAPNET array in northern Fennoscandia, Solid Earth, 2, 303-313, doi:10.5194/se2-303-2011, 2011.

Podvin, P. and Lecomte, I.: Finite difference computation of travel times in very contrasted velocity models: a massively parallel approach and its associated tools, Geophys. J. Int. 105, 271-284, 1991.

Poli, P., Campillo, M., Pedersen, H., and the POLENET/LAPNET Working Group: Noise directivity and group velocity tomography in a region with small velocity contrasts: the northern Baltic shield application to the northern Baltic Shield, Geoph. J. Int., 192, 413-424, 2013.

Redfield, T. F. and Osmundsen, P. T.: The Long -term topographic response of a continent adjacent to a hyperextended margin: a case study from Scandinavia, Geol. Soc. Am. Bull., 125, 184200, 2013.

Redfield, T. F. and Osmundsen, P. T.: Some remarks on the earthquakes of Fennoscandia: A conceptual seismological model drawn from the perspective of hyperextension, Norw. J. Geol., 94, 233-262, 2015.

Sandoval, S., Kissling, E., Ansorge, J., and the SVEKALAPKO STWG: High-Resolution body wave tomography beneath the SVEKALAPKO array: I. A-priori 3-D crustal model and associated travel time effects on teleseismic wavefronts, Geoph. J. Int., 153, 75-87, 2003.

Sandoval, S., Kissling, E., Ansorge, J., and the SVEKALAPKO STWG: High-Resolution body wave tomography beneath the SVEKALAPKO array: II. Anomalous upper mantle structure beneath central Baltic Schield, Geoph. J. Int., 157, 200-214, 2004.

Sharov, N. V.: Lithosphere of the Baltic Shield Based on Seismic Data, Kola Res. Cent., Apatity, Russia, 144 pp., 1993 (in Russian). 
Silvennoinen, H., Kozlovskaya, E., Yliniemi, J., and Tiira, T.: Wide angle reflection and refraction seismic and gravimetric model of the upper crust in FIRE4 profile area, northern Finland, Geophysica, 46, 21-46, 2010.

Silvennoinen, H., Kozlovskaya, E., Kissling, E., Kosarev, G., and the POLENET/LAPNET Working Group: A new Moho boundary map for the northern Fennoscandian Shield based on combined controlled-source seismic and receiver function data, GeoResJ, 1/2, 19-32, 2014.

Silvennoinen, H., Kozlovskaya, E., and Kissling, E.: POLENET/LAPNET teleseismic $P$ wave travel time tomography model of the upper mantle beneath northern Fennoscandia, Solid Earth, 7, 425-439, doi:10.5194/se-7-425-2016, 2016.

Slunga, R. S.: The Baltic Shield earthquakes, in: Imaging and Understanding the Lithosphere of Scandinavia and Iceland, edited by: Bjiimsson, S., Gregersen, S., Husebye, E. S., Korhonen, H., and Lund, C.-E., Tectonophysics, 189, 323-3111, 1991.

Stammler, K.: SeismicHandler - programmable multichannel data handler for interactive and automatic processing of seismological analyses, Comp. Geosci., 19, 135-140, 1993.

Steffen, R., Steffen, H., Wu, P., and Eaton, D. W.: Stress and fault parameters affecting fault slip magnitude and activation time during a glacial cycle, Tectonics, 33, 1461-1476, 2014.

Sutinen, R., Hyvönen E., Middleton, M., and Ruskeeniemi, T.: Airborne LiDAR detection of postglacial faults and Pulju moraine in Palojärvi, Finnish Lapland, Global Planet. Change, 115, 24-32, 2014.

Talbot, C. J.: Weak zones in Precambrian Sweden, Geological Society, London, Special Publications, 186, 287-304, doi:10.1144/GSL.SP.2001.186.01.17, 2001.

Thurber, C. H.: Earthquake locations and three-dimensional crustal structure in the Coyote Lake area, central California, J. Geophys. Res., 88, 8226-8236, 1983.

Thurber, C. H.: Local earthquake tomography: velocities and $V_{\mathrm{p}} / V_{\mathrm{s}}$ - theory, in Seismic Tomography: Theory and Practice, edited by: Iyer, H. M. and Hirahara, K., 1993.
Uski, M. and Korja, A.: Hypocenter distribution of earthquakes in north-western Finnish Lapland: preliminary investigation, Abstract in: The 38th Nordic Seismology Seminar, Helsinki, 1215 June 2007.

Uski, M., Hyvonen, T., Korja, A., and Airo, M.: Focal mechanisms of three earthquakes in Finland and their relation to surface faults, Tectonophysics, 363, 141-157, 2003.

Usoltseva, O., Kozlovskaya, E., Konstantinovskaya, N., and POLENET/LAPNET Working Group Team: Intraplate seismicity in northern Fennoscandia from data of the POLENET/LAPNET experiment, Proceedings of the 9th International Conference PROBLEMS OF GEOCOSMOS, edited by: Troyan, V. N., Semenov, V. S., Kubyshkina, M. V., ISBN 978-5-9651-0685-1, CD disk, 8-12 October, SaintPetersburg State University (SPBU), Saint-Petersburg, Russia, 176-181, 2012.

Van Lanen, X. and Mooney, W. D.: Integrated geologic and geophysical studies of North American continental intraplate seismicity, in: Continental Intraplate Earthquakes: Science, Hazard and Policy Issues, edited by: Stein, S., and Mazotti, S., Geological Society of America Special Paper, 425, 101-112, 2007.

Vinnik, L., Oreshin, S., Makeyeva, L., Peregoudov, D., Kozlovskaya, E., and POLENET/LAPNET Working Group: Anisotropic lithosphere under the Fennoscandian shield from $\mathrm{P}$ receiver functions and SKS waveforms of the POLENET/LAPNET array, Tectonophysics, 628, 2530-2539, 2014.

Virieux, J., Farra, V., and Madariaga, R.: Ray tracing in laterally heterogeneous media for earthquake location, J. Geophys. Res., 93, 6585-6599, 1988.

Waldhauser, F. and Ellsworth, W.: A double-difference earthquake location algorithm: method and application to the northern Hayward fault, Bull. Seism. Soc. Am., 90, 1353-1368, 2000.

Walther, C. and Fluh, E. R.: The POLAR profile revisited: Combined P- and S- wave interpretation, Precambrian Res., 64, 153$168,1993$.

Wu, P., Johnston, P., and Lambeck, K.: Postglacial rebound and fault instability in Fennoscandia, Geophys. J. Int., 139, 657-670, 1999. 